\title{
Sinology, Feminist History, and Everydayness in the Early Republican Periodical Press
}

T

he purpose of sinology is to produce knowledge about China, while the aim of feminist history is to question the very processes through which knowledge is produced. ${ }^{1}$ This article combines these two approaches in examining a set of noncanonical materials published during an often-neglected period of Chinese history. The materials are vernacular periodicals, most specifically China's first commercial women's journal, The Women's Eastern Times (Funü shibao 婦女時報, Shanghai 191117). ${ }^{2}$ The period is China's very early Republic: an era that witnessed the culmination - and foundering - of one of the first and most powerful China dreams, the dream of national strength and an enlightened, genderblind citizenry that drove the 1911 revolution, brought an end to two thousand years of imperial rule, and spawned China's first, faltering Republic. ${ }^{3}$ In the pages that follow, I seek to counter the prevailing scholarly tendency to overwrite this period with narratives of political failure, social stasis, and limited advancement for women. ${ }^{4}$ I do so by highlighting the productive aporias built into the pages of the multigenre, multivocal, and multiregistered Women's Eastern Times.

Characteristic of the genre of vernacular periodicals situated between academic journals and entertainment magazines, The Women's Eastern Times was not defined by an all-encompassing China dream or by an overarching epic vision of what China should become and how it should overcome its (Western-constructed) historical backwardness. It was driven instead by an everyday agenda, which, while in constant dialectical tension with epic as-

${ }^{1}$ For the approach to feminist history referred to in this article, see, for example, Scott (2011).

${ }^{2}$ These materials are vernacular in terms of their cultural register rather than their linguistic register. They were written in a mix of the classical and vernacular languages characteristic of this period. On Funü shibao as the first commercial women's journal, see Ma (1996, 382).

${ }^{3}$ On the four major China dreams in the twentieth and twenty-first centuries, see the introduction to this thematic cluster ( $\mathrm{Da}$ and Wang 2015).

${ }^{4}$ This overwriting is a product of the intellectual May Fourth cultural critique of the late 1910s, which condemned the earlier, broadly popular cultural production of the early 1910s. On recent challenges to the May Fourth critique, see Fan and Fan (1996), Lee (2001), and Chen (2008).

[Signs: Journal of Women in Culture and Society 2015, vol. 40, no. 3]

(c) 2015 by The University of Chicago. All rights reserved. 0097-9740/2015/4003-0002\$10.00 
pirations, was focused on penetrating and recording the details of daily life, on exposing and shaping the experience of the quotidian. ${ }^{5}$ The naturally occurring disjunctions in this quotidian print matter signal cleavages in representation through which traces of history can slip, revealing fragments of the layered dreams, competing aspirations, and gender dynamism of China's early Republic. ${ }^{6}$

Feminism's skepticism of all-encompassing narratives and attentiveness to the multiple and circuitous routes through which knowledge is produced makes materials like The Women's Eastern Times legitimate objects of historical study. ${ }^{7}$ At the same time, sinological attention to the mutating forms of Republican-era written Chinese, and to social, cultural, and historical context, helps to unlock their aporetic richness. In this essay I merge feminist history and sinology in a horizontal reading of the women's periodical press. ${ }^{8}$ This methodological approach to print materials, which is applicable beyond China, the early twentieth century, or gendered journals, aims to capture rather than discipline the chaotic multifariousness of periodical print publications. It involves reading the range of materials within magazines against one another: juxtaposing discursive essays and photographic portraits, polemical articles and commercial advertisements, readers' columns and essay contest entries. The premise of this method is that a journal is much greater than the sum of its articles, and that what journals do is much more complex than what they say they will do or what they may have initially intended to do. ${ }^{9}$ Rather than seek the discursive logic

\footnotetext{
${ }^{5}$ I develop this dialectic between epic and everyday agendas in my book Republican Lens: Gender, Visuality, and Experience in the Early Chinese Periodical Press (Judge 2015).

${ }^{6}$ On this notion of a cleavage, see W. J. T. Mitchell's (1994, 100-107) discussion of the figure of the image/text as a wedge to pry open the heterogeneity of media and of specific representations.

${ }^{7}$ Joan Scott $(2011,3)$, for example, has argued against "[closing] a case by applying a label to it," rather than "[opening] things up by exploring the ambiguous meanings that were attached to intractable problems and unanswerable questions."

${ }^{8}$ This methodology is part of a complex of approaches developed in the context of an ongoing international collaborative project on the Chinese periodical press. This project is now in its second phase, titled "Early Chinese Periodicals Online." The original inspiration for the horizontal method of reading is project member Michel Hockx's Questions of Style (2003). In addition to horizontal reading, the methodology includes integrated and situated readings, which I will not explicitly discuss in this essay. This method of linked situated, integrated, and horizontal readings for multiple publications is greatly facilitated by the tools of the digital humanities. Our project includes the construction of a database (http://kjc-fs -cluster.kjc.uni-heidelberg.de/frauenzeitschriften) that contains comprehensive data on four seminal gendered journals. It is currently being expanded to include other gendered, entertainment, and literary periodicals.

${ }^{9}$ On these premises, see Latham and Morrison (2010) and Lyon (2010).
} 
articulated in selected essays - the prevailing scholarly approach to the periodical press - the horizontal method aims to capture the productive contradictions inherent in these multigenre publications and, by extension, in their surrounding culture.

Such a reading deepens our knowledge of the dramatic changes that altered the course of modern Chinese history by enriching our understanding of the demographic that was arguably most affected by those changesurban women. ${ }^{10}$ It also offers an alternate vision of how early Republican women and men lived these dramatic changes, not exclusively in terms of the series of stark binaries that haunt both the period and later scholarship-East and West, tradition and modernity, weak and strong, past and present-but through blended accommodations grounded in the intimate details of daily life.

\section{The everyday agenda}

China's first commercial women's journal, The Women's Eastern Times, was edited by a man, the journalist, fiction author, and cultural entrepreneur Bao Tianxiao 包天笑, 1876-1973). Bao was an editor at the parent newspaper of The Women's Eastern Times, The Eastern Times (Shibao 時報). He was a natural choice for the editorship of the women's journal not only because of his journalistic background but because he had extensive experience in women's education. ${ }^{11}$ Women had founded journals in China's pre-1911 past and in the early Republic. These publications were always fledgling, however, as they lacked the institutional and financial backing of a well-established publisher like the Shibao Office (Shibao guan 時報館) that produced The Women's Eastern Times. This commercial reality, together with the low rate of female literacy in this period and the Republican regime's formal prohibition of women's engagement in public activities in 1914, ensured that the major women's journals in the 1910s would be founded, edited, and to a certain extent, written by men. ${ }^{12}$

${ }^{10}$ According to Susan L. Mann (2011, xvii), "the movement of women toward work and study outside the home after 1900 was the most significant and sweeping change in China's sex-gender system in centuries.”

${ }^{11}$ On Bao's experience teaching at several women's schools, see Bao $(1974,326 ; 334-$ $45)$.

12 Estimates of women's literacy in the late nineteenth century are as low as 2-10 percent. In Shanghai, where Funü shibao was published, it may have been as high as 25 percent. Other early Republican women's journals run by men include Funü zazhi 婦女雜誌 (The lady's journal, 1915-31), and Zhonghua funü jie 中華婦女界 (Chinese women, 1915-16). 
Bao differed from male "national feminists" who founded women's journals in many other parts of the modern world in that his primary objective was not to harness women's energies to some kind of epic nationalist project-something the censors and the political tenor of the times would not, in any case, have allowed. Grounded in the conviction that the starting and the endpoints of social, cultural, and gender change- and thus ultimately of politics - were the everyday, Bao's mandate was to increase social transparency, transcend long-standing gender taboos, and call a new kind of woman into being. He introduced a series of mechanisms to bring the female reader closer to the text and the text closer to the everyday concerns of the female reader. These included his own editorial column, readers' columns, and essay contests on themes that were directly relevant to women's early Republican lives.

Bao's targeted audience belonged to a new demographic of women I call Republican Ladies - the women ( funü) of the journal's title, The Women's Eastern Times (Funü shibao). His repeated exhortations and strategies for increasing readerly engagement served to consolidate a discursive community of these Republican Ladies. The full plurality of this demographic of women who read, wrote for, and were presumably influenced by the journal only begins to emerge through a horizontal reading of the periodical, however. My reading here will focus on juxtaposing textual constructions of Republican Ladies with the advertisements that helped finance the journal and the photographic portraits that adorned it. ${ }^{13}$ But first a brief geneology of "that name"-funu-that posited a new category of women. ${ }^{14}$

The Women's Eastern Times announced that it was doing something different in terms of gender with its very title-Funü shibao. Similar to previous publications that were labeled "female" in a print culture that did not mark the masculine as an equivalent writing or reading position, this title asserts that The Women's Eastern Times represents an alternative to a cultural norm assumed to be masculine. ${ }^{15}$ At the same time, however, The Women's Eastern Times broke with the previous generic practice of the thirty-odd women's journals published between 1898 and 1912 by using the term funü rather than nü女 or nüzi 女子 in its title. ${ }^{16}$ The journal

${ }^{13}$ Advertisements constituted about 16 percent of each issue of Funü shibas, averaging about twenty ads per issue. They did not constitute a key source of funding for the journal.

${ }^{14}$ Denise Riley (1988) relates feminism's struggle to ways women have been categorized and objectified by "that name"-the reductive term "women"-in history.

15 This point is taken from Margaret Beetham's unpublished manuscript, "Methodological Reflections on the Role of Gender in Defining 'the Women's Magazine.'”

${ }^{16}$ On these various women's journals, see Yin (2000) and Ye (2003). 
thus asserted not only an alternative to a masculine cultural norm but an alternative to prior feminine norms. These norms included the politicized nü or nüzi of previous radical women's journals with strident epic agendas, such as Nüxue bao 女學報 (Women’s learning, 1901-3), Nüzi shijie 女子世界 (Women's world, 1904-7), and Zhongguo xin nïjie zazhi 中國新女界雜誌 (Magazine of the new Chinese woman, 1907). ${ }^{17}$ They also include the genteel, reform-minded nü of the first Nüxue bao (1898) or of Beijing nübao 北京女報 (Beiijing women's journal, 1905-9).

An ancient term, funü was inflected with Western notions of womanhood in the early Republic. ${ }^{18}$ In choosing it as the title for their journal, The Women's Eastern Times's editors were possibly influenced by the contemporary East Asian lexicon through which Western ideals were generally mediated in early Republican China. ${ }^{19}$ Whatever its specific lexical genesis, what is significant is that The Women's Eastern Times's practice set a new precedent. This is evident in the titles of subsequent Chinese publications, most notably the Commercial Press's The Ladies' Journal (Funi zazhi 婦女雜誌, 1915-31), which would remain in print until 1931. The Women's Eastern Times thus established the gender template for what would become the longest running Republican-era women's journal.

The term funü signaled both a specific demographic of women and the particular kind of project in which these women were to be engaged. Focused on change and a better future, this project was transformative and, thus, inherently political. While the journal attempted to ground the new fun $\ddot{\text { in }}$ in the everyday, its aspirations for her reveal an abiding tension between experience and abstraction, everyday preoccupations and epic yearnings, between celebrating the Republican Ladies who were and anticipating those who were not yet. ${ }^{20}$

${ }^{17}$ On these journals, see Xia (2003), Judge (2008b, 23-27), Qian (2008), and passim.

${ }^{18}$ According to the Hanyu dacidian 汉语大辞典. (Dictionary of Chinese), funü is an ancient "common term for mature women" that appears in the $L i j i$ 禮記 (Book of rites) and the Shi ji 史記 (Records of the grand historian).

${ }^{19}$ On Japan's crucial mediating role in early twentieth century China, see Judge (2008b). While many comparable Japanese sources from which much of Funü shibao's content was appropriated used the terms fujin 婦人 (woman) or jo 女 (female) in their titles as had earlier Chinese journals, the Japanese weekly Fujo shinbun 婦女 新聞 (1900-1923) used the Japanese corollary compound for funü. There are many similarities between Fujo shinbun and Funï shibao in terms of content and target audience.

${ }^{20}$ Funü shibao and other women's journals allow us to go beyond the intellectual articulation of what Tani Barlow $(2004,16)$ has called the "future anterior," as these materials include evidence of both women's (inevitably mediated) experience and examples of the projects that framed that experience. 
Bao Tianxiao defined the kinds of information the new Republican Ladies either possessed, required, or were called upon to share. In his solicitation for submissions to the journal he prioritized subjective writings: reflections on women's practical experience (shiyan tan 實騐談) headed his list, followed by diaries (riji wen 日記文) and personal views on society and customs. Next were discussions of such topics as "domestic science" (jiazheng 家政), human relations (jiaoji 交際), and fine arts, together with essays on letters (shujian wen 書簡文). Bao also directly requested that women of good reputation (mingyuan 名媛) send in photographs, preferably of themselves, but also of their schools and families, or of their own works of calligraphy, painting, or embroidery (Bao 1911).

Bao reiterated this call for personal photographs in his editorial column. ${ }^{21}$ Insisting that the women who wrote for the journal become real to their audience not only through their written words but through their visible images, he repeatedly solicited their portraits. His constant prodding was necessary as the Republican Ladies he targeted were generally reluctant to allow their images to circulate in print, a practice that had been associated with courtesans since the late 1890s (Judge 2012).

Bao also used this editorial platform to converse with his readers, setting the parameters for both the content of the magazine and for the Republican Lady's acceptable realm of concerns. He declared swine herding off limits, for example, as it was a less dignified female occupation than sericulture, beekeeping, or even raising chickens (Bao 1911, 3:87). At the same time, he encouraged women to be the first in Chinese history to speak candidly and openly about their own reproductive health. He applauded a female-authored article on the difficulties of childbirth and angrily defended it from the charge that it was "not sufficiently refined" (Bao 1911, 2:56). Bao further shaped the everyday content of the journal through a series of essay contests on such topical themes as local marriage customs, women's regional occupations, household hygiene, and women's need for basic medical knowledge. ${ }^{22}$

Finally, Bao included two separate readers' columns in the journal, which appeared early and late its history. ${ }^{23}$ The two columns differed in tone and

${ }^{21}$ Bao's column was titled "From the Office of the Editor" ("Bianji shi” 編輯室) and from issue 18 on, “Conversation from the Office of the Editor” “Bianji shi zhi tanhua” 編輯室之 談話). It appeared in ten of Funü shibao's twenty-one issues.

${ }^{22}$ Essay contests were announced in sixteen of the journal's twenty-one issues.

23 “Duzhi julebu” 讀者俱樂部 (The reader’s club), Funü shibao 3 (October 1911), 8384; Funü shibao 7 (July 1912), 82; “Funü tanhua hui” 婦女談話會 (Women's conversation association), Funü shibao 18 (June 1916), 71-77; Funü shibao 19 (August 1916), 75-82; Funï shibao 20 (November 1916), 81-88; Funï shibao 21 (March 1917), 70-76. 
content, indicating a deepening of the everyday agenda over the course of the journal's history and an increase in the active engagement of female readers. While the first column is more prescriptive in tone, repeating many of the familiar tropes of the epic nationalist discourse such as the need for women's education, the scourge of foot-binding, and the frivolity of the female consumer, the second column offers more descriptive writings that are closer to the grain of women's everyday experience. The latter includes, for example, instructions on how to fashion shoes that would make unbound feet more attractive, and advocacy for a women's club that would include, among its many services, medical tests for prospective wet nurses (Qiu 1916; Zhang 1916).

\section{Republican Ladies}

Textual and mediated, the female voices refracted through these reader's columns nonetheless add depth to Bao's — and other male authors'-projected image of the Republican Lady. Photographs and advertisements further help to fill out this composite portrait. Despite the Republican Ladies' genteel reticence about circulating their images in print, a remarkable number answered Bao's call. A little over 25 percent of the 485 photographs that were published in The Women's Eastern Times, some 125 portraits in all, were of the journal's authors and their social peers (Judge 2012). Read in conjunction with illustrated medical advertisements that appeared in the journal, these portraits provide evidence of the range of female subject positions subsumed under the category of funü.

There are several reasons for using medical advertisements as prisms onto early Republican notions of gender. The first is their pervasiveness in the Chinese periodical press. From the beginning of newspaper advertising in China in the 1860s, pharmaceutical advertisements have represented the greatest number of advertisements in the press after ads for print products (Mittler 2013, 205). ${ }^{24}$ By the 1900s, the most prominent advertisers in the Chinese press were those selling patent medicines (Mittler 2013, 305). Second, because medical advertisements address the practical issue of bodily health, they are particularly rich in data on everyday concerns. Together with lengthy narratives that describe the properties of the advertised medicines, they include personalized testimonials to the medicine's efficacy that are often accompanied by a drawn or photographic portrait of the subject of the testimonial. The testimonials detail symptoms,

\footnotetext{
${ }^{24}$ See also Huang $(1988,2012)$.
} 
describe the patient's near desperation in seeking a cure, and reveal how the miraculous pills or tonic were finally discovered. While it is difficult to ascertain whether these testimonials were penned by individuals who actually took the medicine, Carl Crow (1884-1945), who opened the first Western advertising agency in China in 1918, argues that they were. ${ }^{25}$ Even if authentic users did not write the narratives, local authors would have: many journalists wrote both articles for publications like The Women's Eastern Times and ad copy for big advertising companies. ${ }^{26}$ The testimonials therefore reflect either actual everyday experience in the early Republic or informed assumptions about that experience. The third reason medical advertisements are a valuable source is because the health-obsessed consumers of the journals avidly read them. ${ }^{27}$ They had to be convincing to the targeted readers of the journal and potential purchasers of the product.

Advertisements include a wealth of information for researchers in various fields, from commercial culture to medicine. Our focus here is on what they potentially reveal about two specific topics: the elusive female reader of The Women's Eastern Times and the blended notion of the physical body in the early Republic.

The first advertisement is for a product called Running Blood (Zilai xue 自來血). Among the ad's several components is a photograph of the wife of Tang Linbao 唐麟保, an instructor at the Zhenjiang police headquarters, after she had been treated with Original Blood. It also includes a description of the range of ailments the medicine addressed and a testimonial authored by Tang describing his wife's illness and her posttreatment transformation. In his testimonial, Tang announced that he planned to publish the portrait of his wife in all newspapers in the hope that more

\footnotetext{
${ }^{25}$ According to Crow $(1937,213)$, it was easy to secure genuine testimonials in China. If a Chinese person was induced to take a remedy and found it efficacious, he would have no objection to writing a letter that could be used in advertising with no expectation of being paid. From as early as 1872 , Chinese advertisements that previously had been endorsed by the scholarly or imperial elite began to include testimonials from individuals who had actually used the product (Mittler 2013, 285).

${ }^{26} \mathrm{Xu}$ Zhuodai, who contributed several pieces of fiction to Fun $\ddot{~ s h i b a o, ~ w a s ~ t h e ~ b e s t ~}$ writer of advertising copy for the "king” of native Chinese advertising, Huang Chujiu 黄楚九, manager of Great China-France Drugstores (Zhong Fa da yaofang 中法大藥房). See Cochran $(2006,53)$. Foreigners could not write copy that would effectively appeal to a Chinese audience (Sanger 1921, 72).

${ }^{27}$ On avid readers of advertisements, see Sanger $(1921,61)$. For a characterization of late traditional Chinese as "hypochondriacs, obsessed with diets, medicines, and health generally," see Elvin $(1989,277)$.
} 
women with similar ailments could find relief. It is unclear whether his wife was insufficiently literate to pen the testimonial herself or too modest to allow her words to circulate in public. Given that she made the even bolder gesture of consenting to the circulation of her image in the periodical press, the former seems more likely ("Nengzeng nüjie" 1911).

The photograph of Tang's wife (fig. 1) is a classic full-bodied studio portrait of an upright woman. She is dressed demurely in wide pants and a long, loose fitting tunic. Her feet-small but visible-appear to be unbound.

Tang's wife stands in for one segment of the demographic of Republican Ladies, women who did not write for The Women's Eastern Times but who were spoken to and for in the pages of the journal. Her portrait is similar to that of the regal wives of officials, including the one in the photograph in figure 2, women whose identities, like that of Tang's wife, were subsumed under those of their husbands.

The Running Blood advertisement reflected the norm for medical ads in The Women's Eastern Times: only four of the fifty advertisements for women's health products printed in the journal included testimonials written in a woman's voice. I will discuss two of these allegedly femaleauthored advertisements here as they appealed to two of the journal's key constituencies: teachers and students in China's new-style girls' schools. The underrepresentation of these women's voices in the advertisements reflects deeply entrenched social taboos against women openly discussing their own physical maladies. It further parallels the long established practice of men discussing their wives' or daughters' health with male doctors outside the sickroom where women were attended by less authoritative female relatives, midwives, or healers. The female-voiced advertisements that countered these practices and taboos were more closely aligned with the journal's editorial agenda, which actively encouraged women to openly discuss their reproductive health. ${ }^{28}$

The second advertisement to be considered here presents a sharp contrast to the Running Blood text. Not only is the testimonial written in the voice of a woman, it is written in the voice of a Westernized professional woman, Chen Zhene 陳珍娥, a teacher at a missionary school, the ZhongXi nüxuetang 中西女學堂 (Sino-Western Girl's School) in Shanghai. The accompanying image is not a photograph but a drawing of Chen in lacy

${ }^{28}$ I address the construction and rhetorical uses of the notion of these taboos at greater length in Republican Lens (Judge 2015), particularly chapter 4, "Public Bodies." 


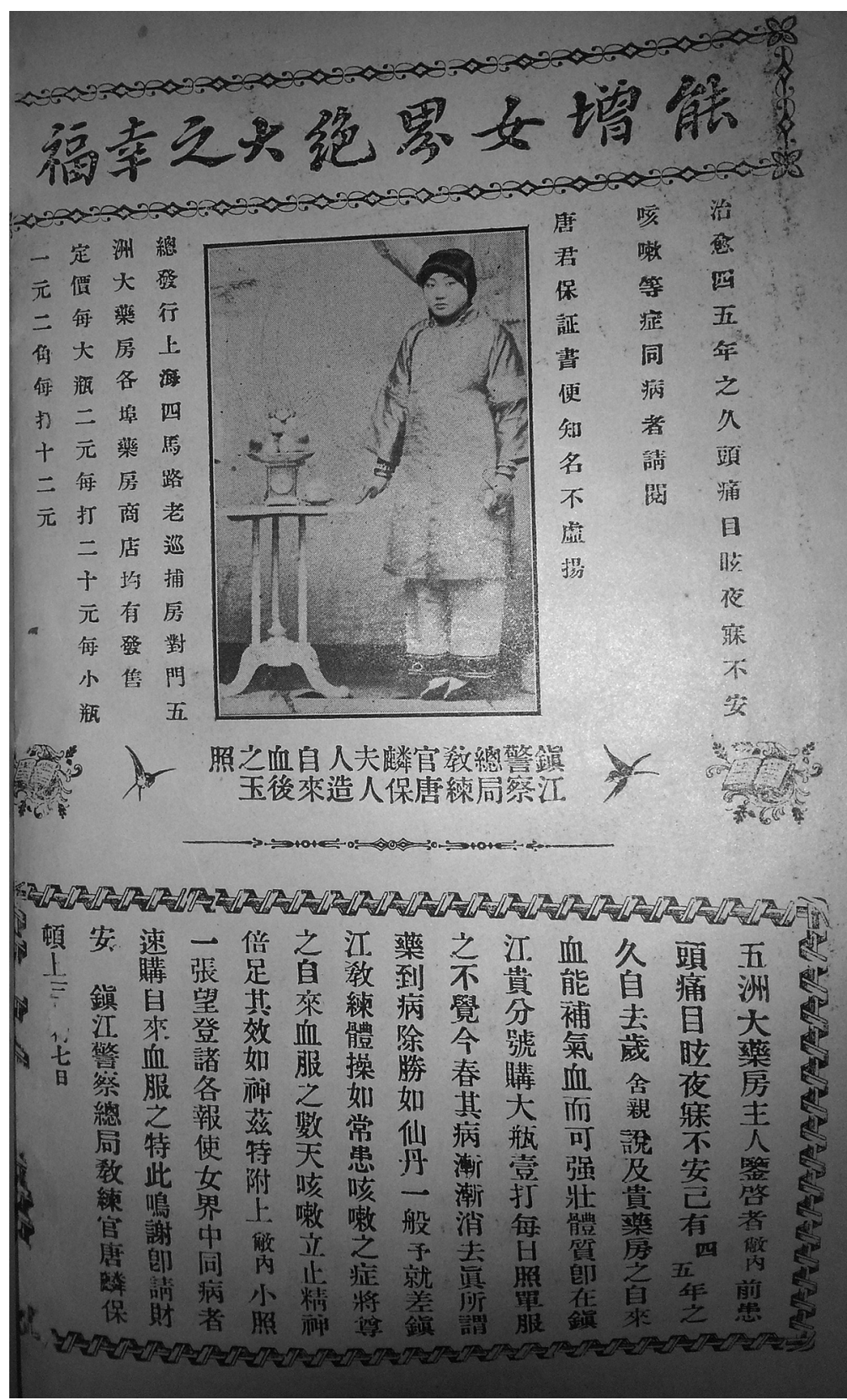

Figure 1 “Nengzeng nüjie jueda zhi xingfu” 能增女界絕大之幸福 ([This product can] greatly enhance the happiness of women). Funï shibao 2 (July 26, 1911); 3 (September 22, 1911); 4 (November 5, 1911). Courtesy of Shanghai Library. 


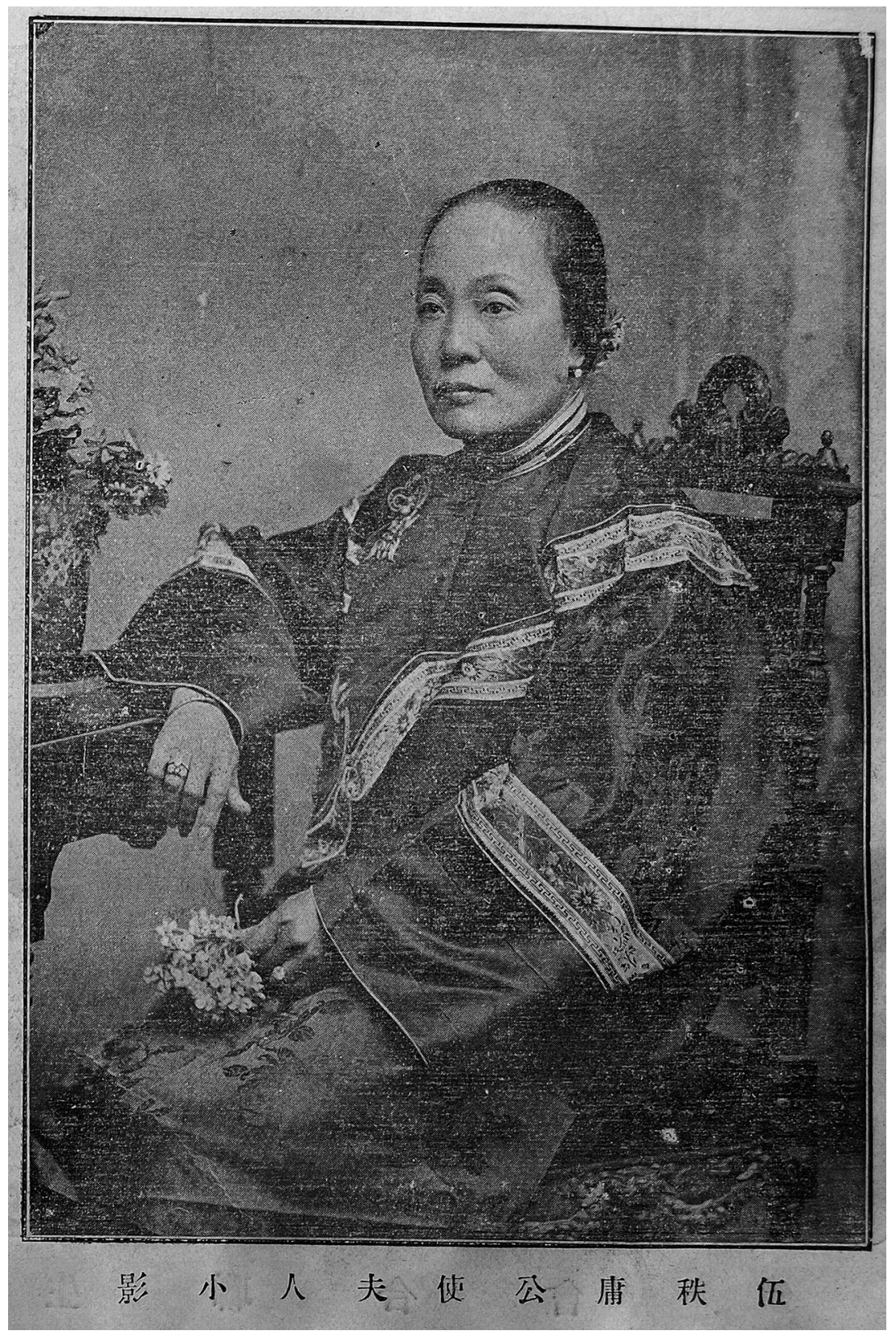

Figure 2 Wife of Ambassador Gongshi 公使 Wang Botang 汪伯棠 (Wang Daxie 汪大隻 [1860-1929]). Funü shibao 2 (July 26, 1911). Courtesy of Shanghai Library. 


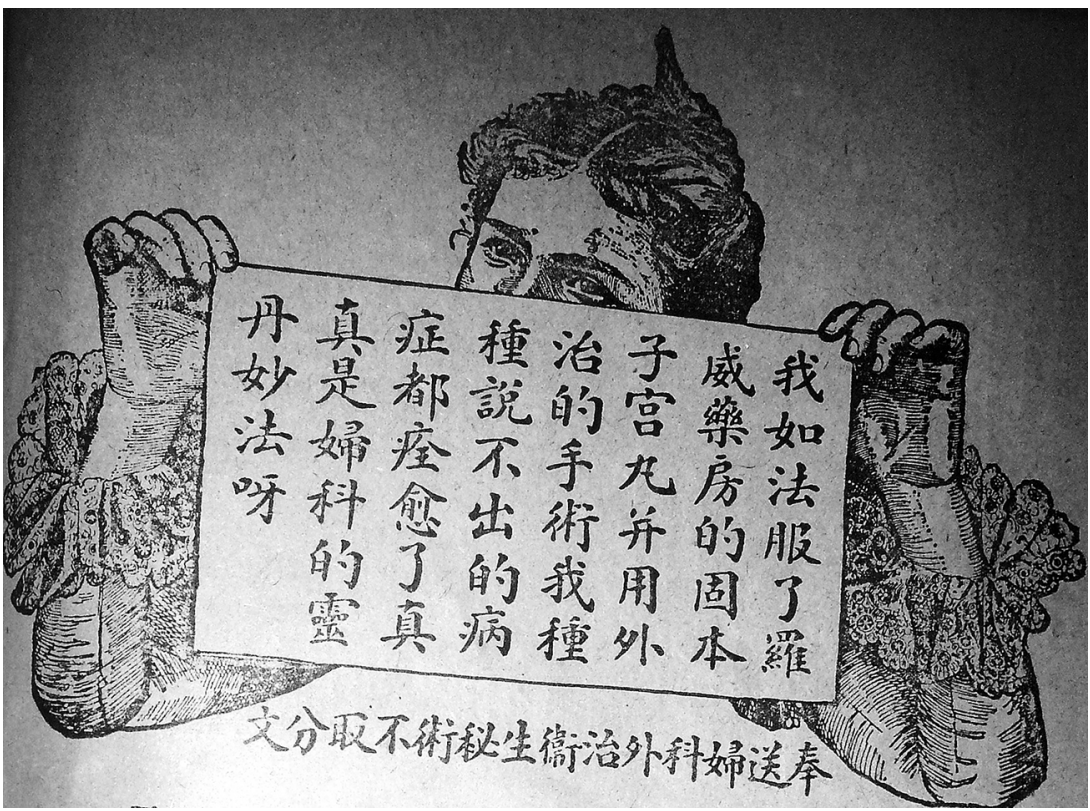

Figure 3 Chen Zhene 陳珍娥. Funü shibao 2 (July 26, 1911). Courtesy of Shanghai Library.

Western sleeves. She is holding up a placard that proclaims that all of her unnamable diseases were cured after taking the Luowei Pharmacy's Guben Medicine for the Uterus (Guben Zigong wan 固本子宮丸; see fig. 3).

Underneath the placard is a more detailed testimonial also penned by Chen but focused on a second drug produced by the Luowei Pharmacy, Red Blood Wheel Tonic (Hongxue lun buyao 紅血輪補藥). Chen highlights several effects of the tonic, including facilitating walking. Without making any direct reference to foot-binding, she appears to be addressing women with recently unbound feet. She claims that the medicine effectuated a complete physical transformation-as if two different people inhabited her body before and after the treatment ("Wu rufa" 1911).

Chen Zhene has left no historical traces that I have been able to find. She had her direct corollary, however, in a number of educators featured in The Women's Eastern Times's photographs and essays, women who may have shared Chen's ailments and benefited from the Luowei's pharmacy's cure. Included among the women whose photographic portraits appear in the journal are the educator and journalist Lü Bicheng 呂碧城 (1883-1943); the founder of an orphanage for poor children, Cao Rujin 曹汝錦 (b. 1878); and the physical education specialist Tang Jianwo 湯劍我一who wears lacy 
Western sleeves similar to Chen's in the advertisement's illustration (fig. 4). ${ }^{29}$

A third advertisement introduces still another subdemographic of women. Whereas the first Running Blood advertisement was written in the husband's prose and the second in a woman's prose, the third combines a woman's prose with two poems in the qilu verse form (consisting of eight lines of seven syllables, with a strict pattern and rhyme scheme). Visual differences between the three advertisements are also marked. Whereas the first was illustrated by a photographic portrait of a respectable wife and the second by a sketch of a Westernized girls' school teacher, the third was enhanced by an ink drawing of a young woman in fashionable Chinese dress seated at a desk in an old-style study (fig. 5). The young woman is identified as Lin Yingfei 林影斐 of southern Hunan province. The narrative includes both a testimonial to the drug's efficacy and a gesture of thanks to the drug maker. In this case the medicine is Moon Brand Pills (Yueguang tiewan 月光鐵丸) and the manufacturer the Sino-French Old Pharmacy (Zhong-Fa lao yaofang 中法老藥房; “Xiangnan” 1911, back matter).

This third advertisement most directly links women's health to the epic themes of women's education and national salvation. Echoing the standard tropes of the nationalist discourse, Lin asserts that it is crucial for women to study if the nation is to be strengthened. At the same time, however, she situates this discourse within the quotidian realm and relates it to the physical challenges that Chinese women had historically faced in seeking an education. Invoking the romantic and desirable ideal of the sickly elite woman of talent, Lin asserts that female students in the early twentieth century were no different from talented young women of the past who endured poor health and died young while cultivating their literary abilities. ${ }^{30}$ Lin herself had become physically depleted by eleven years of studying and seeking to contribute to the enlightenment of Chinese women. It was not until she discovered this “panacea [shengyao 聖藥] for obstetrical and gynecological issues [fuke]" through a newspaper advertisement that her health improved and her vigor returned. In addition to expressing her gratitude to the head of the Sino-French Old Pharmacy, Lin's two poems explained to her female compatriots that talented and beautiful women were no longer doomed (hongyanboming 紅顏薄命).

${ }^{29}$ The captions to these three photographs read: "Portrait of the educator Lü Bicheng," Funü shibao 2 (July 26, 1911); "Photograph of child care class at the Shanghai Institute for Poor Children, 1910, Ms. Cao Rujin 曹汝錦 (b. 1878), founder of this institute and wife of Zeng Zhimin 曾志莣 [1879-1929],” Funü shibao 2 (July 26, 1911); “Physical education specialist 體育家 Tang Jianwo (tiyu jia 湯劍我) in Western dress,” Funü shibao 2 (July 26, 1911).

${ }^{30}$ On late imperial women of talent dying young, see Ko (1992). 


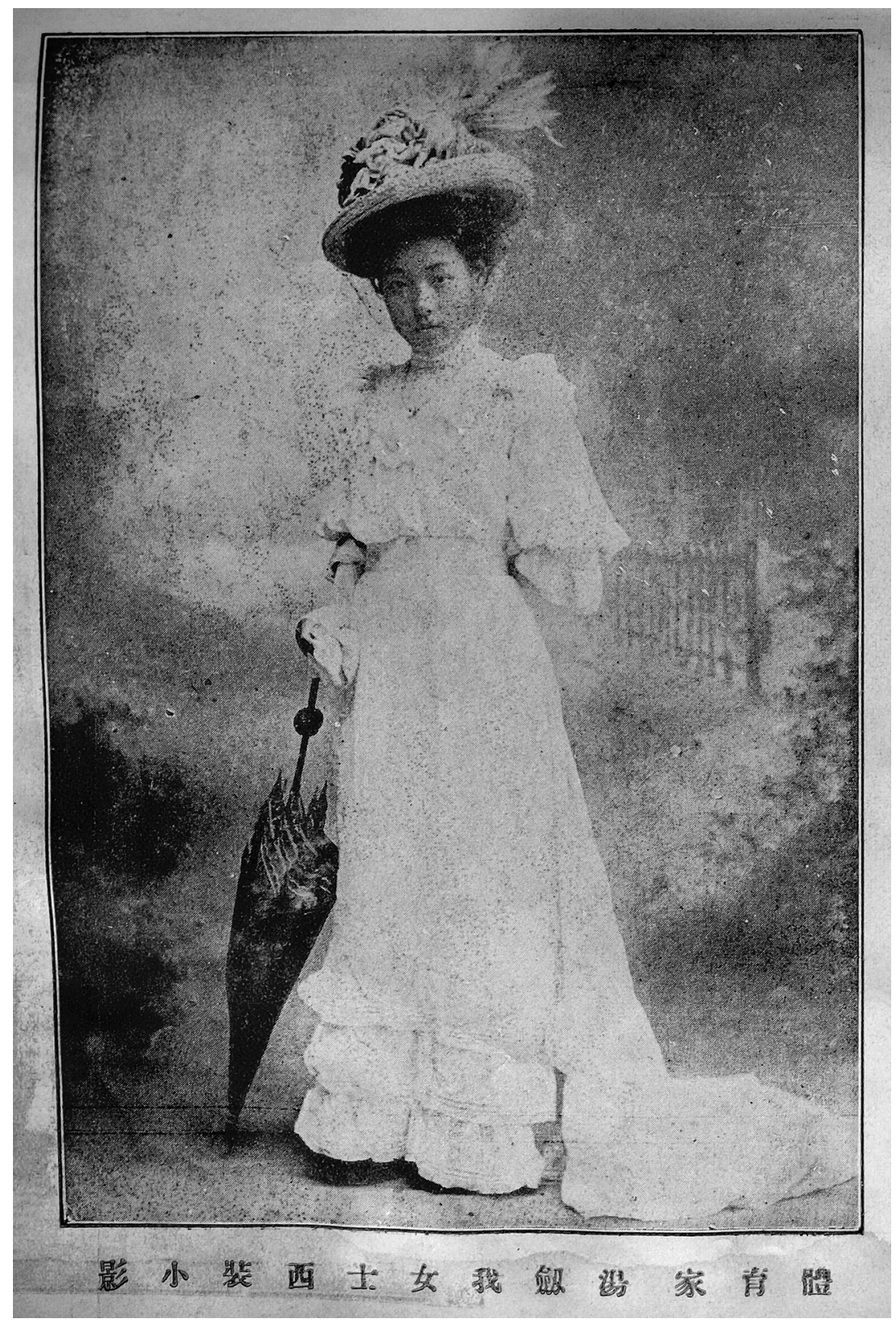

Figure 4 Physical education specialist 體育家 Tang Jianwo 湯劍我 in Western dress. Funü shibao 2 (July 26, 1911). Courtesy of Shanghai Library. 


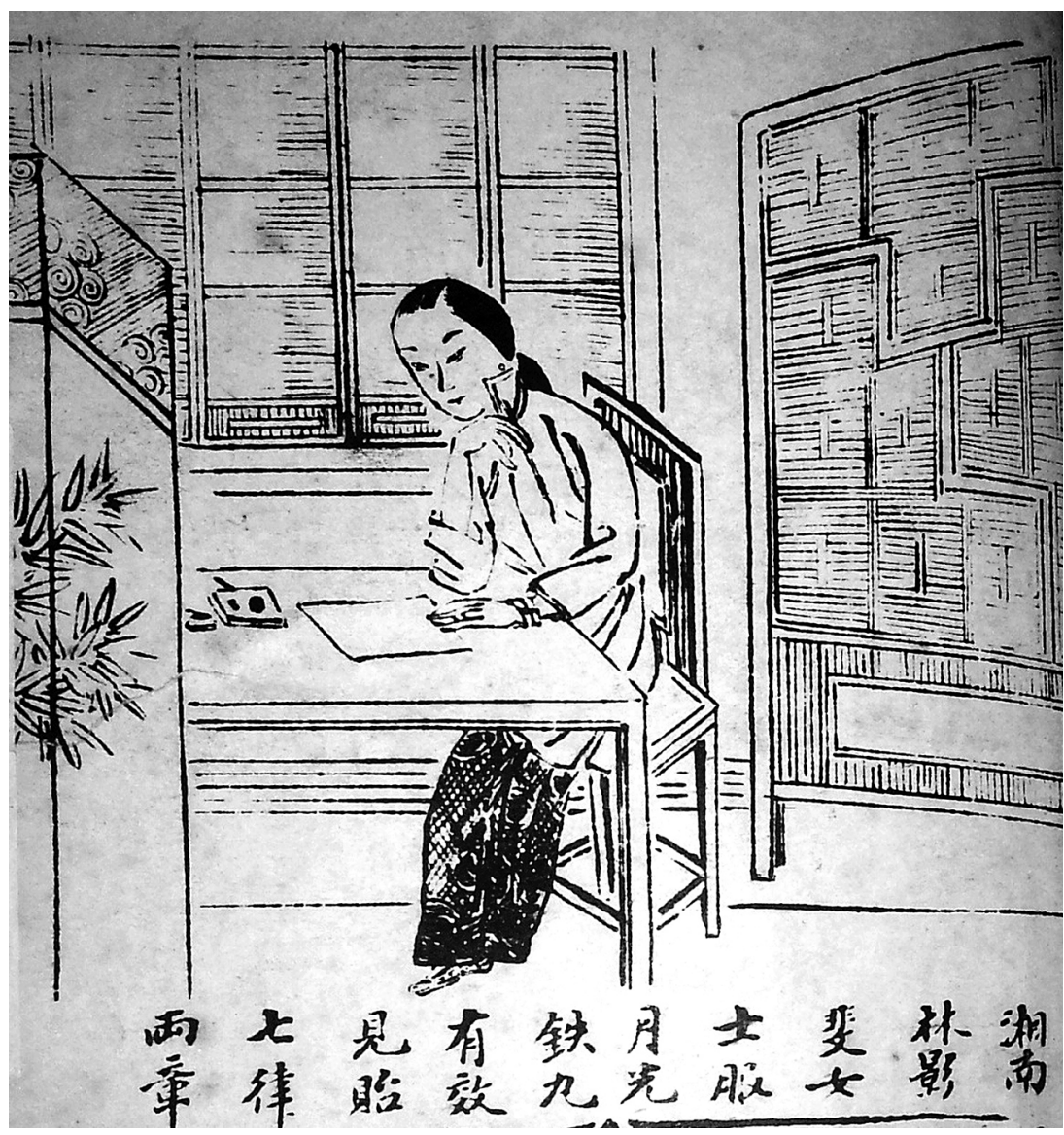

Figure 5 “Xiangnan Lin Yingfei nushi fu Yueguang tiewan youxiao jiantai qilu liangzhang” 湘南林影斐女士服月光鐵丸有效見胎七律兩章 (The Yueguangtie pills have good effects on Ms. Lin Yingfei from Xiangnan. She composed two poems [to thank the drug maker]). Funï shibao 2 (July 26, 1911), back matter. Courtesy of Shanghai Library.

With the help of Moon Brand Pills they could become cured-sickly talented-beauties and national heroines ("Xiangnan" 1911). ${ }^{31}$

Just as Tang Linbao's wife in the first advertisement had her corollary in the wife of Wu Tingfang, and Chen Zhene was mirrored in the dynamism of Lü Bicheng, Cao Rujin, and Tang Jianwo, Lin Yingfei stood in for the many women who used long-standing poetic forms to express a range of

${ }^{31}$ I am grateful to one of the reviewers of this article for this formulation of the "curedsickly-talented-beauty" and for pushing me to emphasize the positive associations of the sickly woman of talent. 


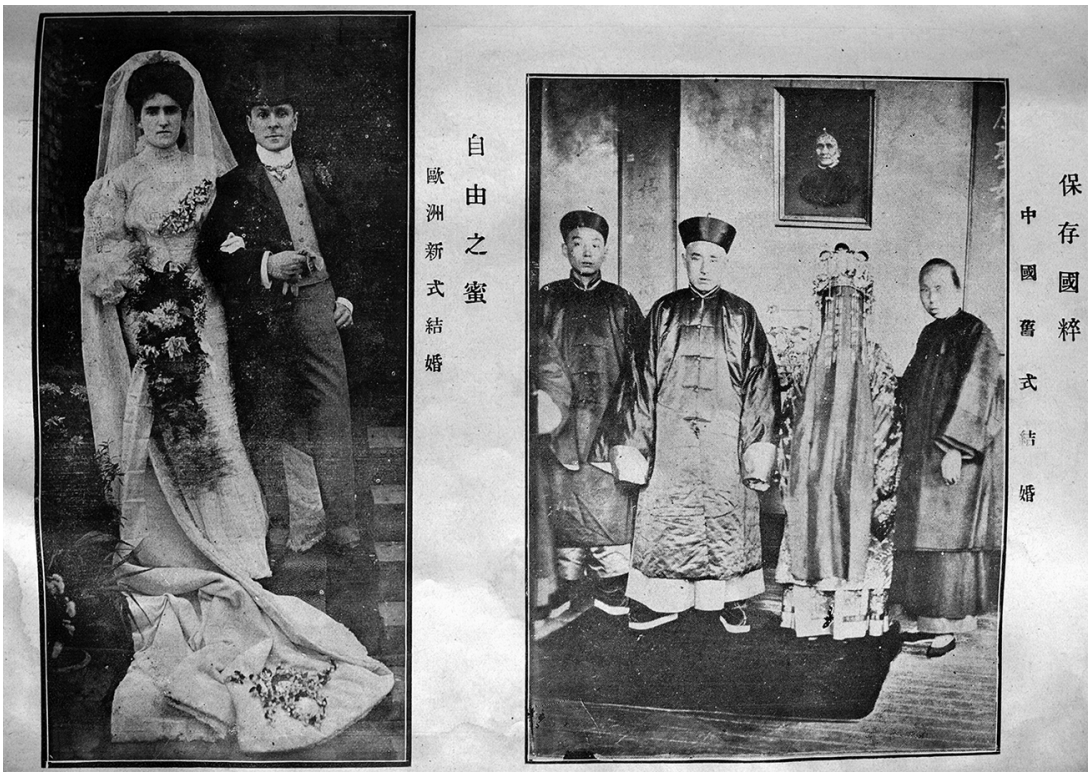

Figure 6 "Preserving the national essence" (baocun guocui 保存國粹): “Chinese old-style wedding” ( jiushi jiehun 舊式結婚; photograph on right). “The sweetness of freedom” (ziyou zhi mi 自由之蜜): “European new-style wedding” (photograph on left). Funü shibao 2 (July 26, 1911). Courtesy of Shanghai Library.

personal, social, and political concerns in the pages of The Women's Eastern Times. Each issue of the journal featured between ten and twenty poems in the form of $s h i$ 詩 and $c i$ 詞.

The Women's Eastern Times advertisements and photographs thus reveal both the capaciousness and the limitations of the category of fun $\ddot{\text {. }}$ They invoke and represent wives of officials too discrete-or unletteredto write testimonials themselves but willing to have their portraits published in the periodical press. They also mirror professional women working in new educational institutions, and students committed to learning for the nation. In casting the alleged dichotomies between old-style genteel women and new-style students, between sickly women of Asia and strong citizens, onto a singular viewing plane, they also subtly align Eastern and Western bodily practices.

\section{Blended bodies}

The Women's Eastern Times is not devoid of powerful civilizational binaries such as in the dual wedding portrait (fig. 6) below. East and West were also sharply dichotomized in a number of the journal's topical essays. In one 
such essay, an author who used the pseudonym Xingyi 星一 and published several articles on the United States in The Women's Eastern Times set up a series of binaries comparing American and Chinese standards of beauty and female physical attributes. While American women are vital (xianyan 鮮妍) and as brave and sturdy (yongjian 勇健) as men, Xingyi stated, their delicate ( jiaoruo 嬌弱) Chinese counterparts are so weak they can hardly bear the weight of their own clothing (ruobushengyi 弱不勝衣). Tall and erect (tingting yuli 亭亭玉立), American women tower over hunchbacked (yulou 傴僂) Chinese women who are so willowy (niaonuo 昗娜) they could float on the wind (suifeng piaoqu隨風飄去). These markedly different levels of physical fitness were further reflected in personal countenance: while American women have natural color (yanse guangze 顏色光澤), Chinese women's ashen complexions (mianse huisi 面色灰死) are smeared with red makeup (tuzhu fufen 塗朱傅粉). The source of this great divergence was medical: American women were superior because they were more attentive to health (weisheng 衛生) (Xingyi 1911, 52).

Essays like Xingyi's posited clear prescriptive dualities. The West was equal to strength, was equal to positive; the East was equal to weakness, was equal to negative. Not all female readers of The Women's Eastern Times would have concurred with Xingyi's polemical representation of this binary, however. The image of a robust and strapping American woman would have been anathema to well-bred Chinese women, even to many of those who were well educated and worldly. Yet it was not unwelcomingly foreign to all. Further extending the complex range of female potentialities in this period are Chinese women who had already chosen to abandon the subject position of the willowy Chinese beauty in favor of the more robust bearing Xingyi had reserved for American women. His claims appear not only exaggerated but meaningless when juxtaposed with the photograph of and articles by the (vital and sturdy) physical education specialist Tang Jianwo 湯劍我 (see fig. 4 above, and Tang 191 la, 1911b, 1911c, $1911 \mathrm{~d}$ ). Tang's physical demeanor in her stylish photograph and the physical education expertise she shared in four articles published in The Women's Eastern Times challenge Xingyi's description of the gulf-or at least any notion of the intractability of the gulf-between weak and wan Chinese women and their physically fit and health-savvy American counterparts.

Tang, who was educated in Japan and married to Xu Zhuodai 徐卓呆 (1881-1958), principal of the first physical education school in Shanghai during the last years of the Qing dynasty, self-consciously collapsed the binaries between East and West, weak and strong in her writing. ${ }^{32}$ In her

${ }^{32}$ On Tang, see Yu $(2009,118)$. On Xu, see Link (1981, 158, 163). 
article "On Exercises for Women" she refuted the notion that Western culture was inherently inclined toward physical fitness. The concern with exercise was a modern (jindai 近代) development even in Europe, she asserted, not something that had existed since ancient times (Tang 1911d, 7). And while she cited a report of the German Medical Society (Yixue xuehui 醫學協會) in underlining the links between strong female and national bodies, she fused this foreign message with local preoccupations: physical exercise would not only build up physical immunity but boost moral immunity and quiet excitable imaginations (Tang 1911d, 9-10).

Tang's cosmopolitan assimilation is further evident in her article on rope exercises for the family. In illustrating the article with Victorian-style figures (fig. 7), she used Western practices to model Chinese behavior rather than diminish it, and suggested the potential for bodily transformation, not the incommensurability of bodily difference.

Tang also defied the stereotype of the pathologically modest Chinese woman (mirrored in the advertisement featuring Tang Linbao's wife) who dared not discuss the most intimate female bodily processes not only with men but with other women and even with their own doctors. ${ }^{33}$ She outlined a series of exercises for gynecological problems, breaking the taboo against discussing the “filthy and impure” ( huizhuo 穢濁) menses. She also attenuated the stigma of menstruation as a gender-specific source of physical weakness by pairing menstrual ailments (yuejing bing 月經病) with presumably gender-neutral hemorroidal afflictions (zhixue guan 痔血管) in her detailed physical drills (Tang 1911a, 75).

While Tang was one of a small handful of women to directly address the issue of menstruation in the pages of The Women's Eastern Times, advertisements catapulted the topics of menstruation and other gynecological issues into the public realm, reinforcing Bao Tianxiao's editorial mission of overcoming oppressive and benighted taboos. The advertisements also suggest the medical pluralism of the early Republic. ${ }^{34}$ While their narratives relied on local notions of the body to discuss illness, advertisers stamped their various products with the imprimateur of Western science.

All three of the advertisements discussed above are rooted in Chinese medical discourse. Each focuses on Blood, which had been understood as the defining essence of female health from the time of the Yellow Emperor's Inner Classic (the contents of which date to the second and first centu-

${ }^{33}$ On this stereotype, see, e.g., Qu $(1911,25)$.

${ }^{34}$ Nathan Sivin $(1987,194)$ has also argued that in the Republican period there was no dualistic choice between "Chinese medicine" and "Western medicine" but rather a notion of medical pluralism. 

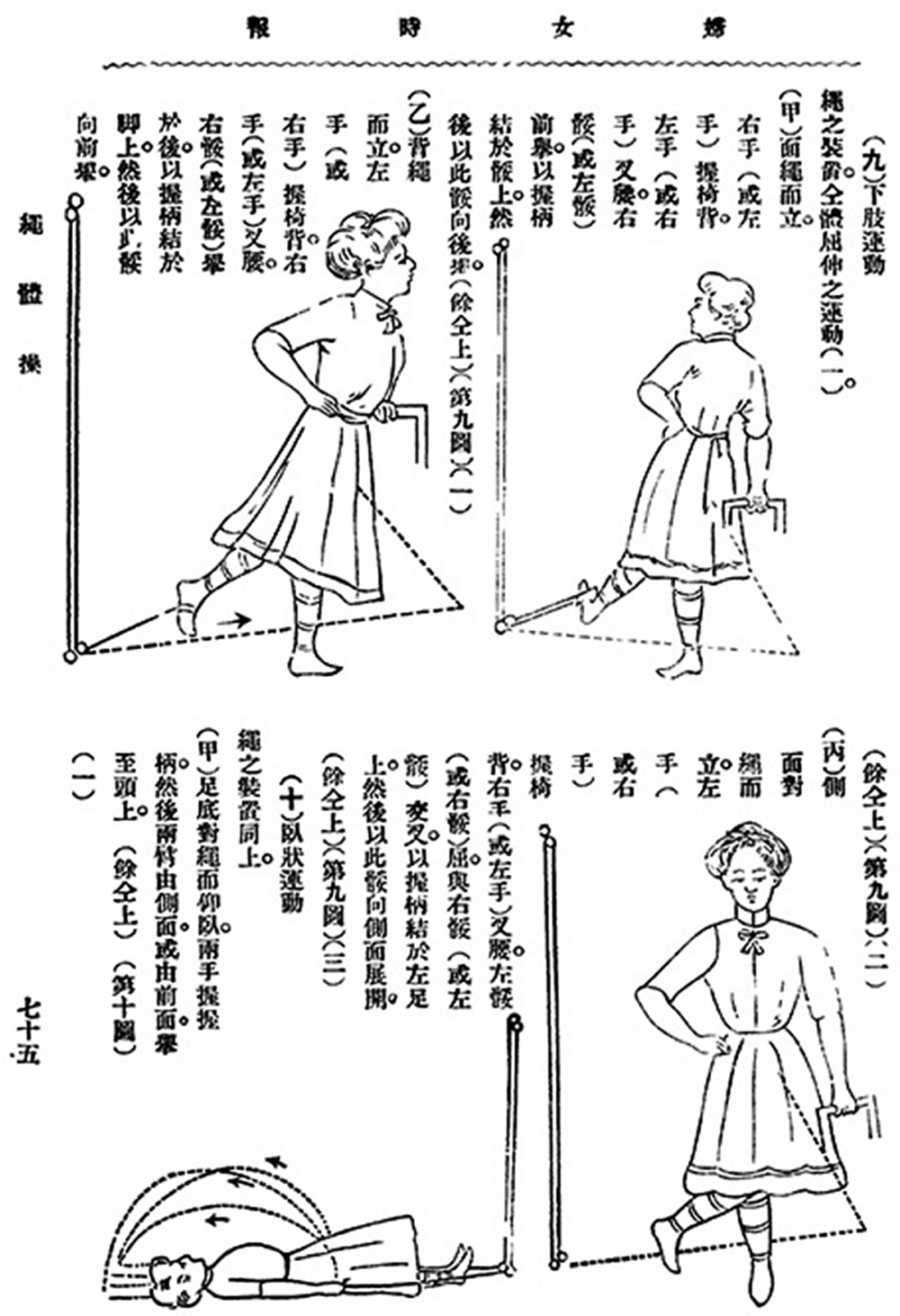

Figure 7 Tang Jianwo 湯劍我. [Jiating yundong] Shengticao [家庭運動]繩體操 (Rope exercises [for the family]). Funü shibao 2 (July 26, 1911), 71. Courtesy of Shanghai Library.

ries BCE). ${ }^{35}$ Tang Linbao described how his wife had suffered for a period of four or five years from Blood depletion, manifested in headaches,

${ }^{35}$ Blood remained the seminal principle of women's medicine in the Song Dynasty, when obstetrics and gynecology (fuke) became a discrete field. It continued to be of paramount importance through the Ming and Qing dynasties even as the universal rather than gendered 
troubled sleep, cough, and other symptoms. When he learned that the Great World Pharmacy's Running Blood could boost qi and Blood ( $b u$ qixue 補氣血) and strengthen the body, Tang rushed to purchase it ("Nengzheng" 1911). The teacher Chen Zhene also suffered from Blood depletion and was saved by the replenishing Red Blood Wheel Tonic. She also promoted Guben medicine for the uterus, which the Luowei drug company claimed was so effective in treating gynecological ailments related to menstruation and leucorrhea (baidai 白帶) that it offered a moneyback guarantee if symptoms did not disappear ("Wo rufa" 1911). Similarly, Moon Brand Pills had been a panacea for Lin Yingfei’s undisclosed gynecological disorders.

In addressing the dangers of Blood fatigue and Blood depletion, and the need for Blood-nourishing remedies, these various medical advertisements were on a continuum with Qing dynasty (1644-1911) gynecological texts. At the same time, however, the medicines boasted a foreign cachet. This is evident in the very name of the three Chinese pharmacies whose products were featured in the journal: all are identified as yaofang, a new term for Western-style pharmacies rather than tang 堂 or hall, the term for old-style Chinese drugstores (Cochran 2006, 54). Although the Great World Pharmacy — which had more advertisements in The Women's Eastern Times than any other drug company - and the Sino-French Old Pharmacy were both Chinese companies founded in Shanghai near the turn of the century, both posited global connections in their names. ${ }^{36}$ The Luo Wei Pharmacy, also based in Shanghai, proclaimed that its Red Blood Wheel Tonic was custom made in England's most famous pharmaceutical factories (yoochang 藥廠; “Wo rufa” 1911; Huang 1988, 150). Old ailments required blended remedies suited to the new age.

\section{Conclusion}

Early twentieth-century women's periodicals offer rare insights into the articulation between the grand narratives and structuring binaries of the period, and the materiality of everyday life. Carefully constructed photographic montages and essays of admonition presented the journals' viewers and readers with a stark critique of the inadequacy of their traditions

dynamics of bodily function were increasingly emphasized (Furth 1999, chap. 2; Wu 2010, 28-29, 87).

36 The Great World Pharmacy was in founded in 1907, and the Sino-French Old Pharmacy - if it is the same as the Sino-French Pharmacy—-would have been founded in Shanghai in 1887. On these new-style pharmacies, see Huang $(1988,150)$. 
and the weakness of their women. This epic agenda was powerfully diffused, however, in photographs, writings, and advertisements printed in the pages of the same journal that transcended gender stereotypes, ignored alleged taboos, and dissolved stark dichotomies. It is in the cracks between the larger expository narratives and the smaller stories-captured in female-authored articles, illustrations, or testimonials on pharmaceutical products - that we can glimpse the ways individuals may have negotiated the challenges of the era.

Making sense of the rich and often inchoate materials contained in these smaller stories requires an approach that combines the methodologies of feminist history and sinology. Feminism's skepticism of closed narratives and its broad conception of knowledge production recognizes these multigenre, multivocal, and multiregistered materials as invaluable objects of historical study. Although these materials are far removed not only from classical philosophical but also from modern literary sinological canons, sinological skills are critical to uncovering their full import. Knowledge of historical precedents and linguistic conventions makes it possible to discern the palimsestic nature of new meanings in the early Republic as novel notions settled into the cracks of prior sedimentations, revealing, for example, the embeddedness of seemingly new discourses on the body in old cosmologies, and the subjective links between the experience of illfated late imperial woman of talent and nation-minded new-style female students.

A combined approach thus allows us to probe the ways "big history"the purview of old-style sinological knowledge-intersects with the smaller projects of everyday life. ${ }^{37}$ Properly contextualized, the haphazard but finegrained detail contained in the pages of the women's periodical press yields invaluable insights into the complex historical processes that shaped modern China.

History Department

York University

\section{References}

Bao Tianxiao 包天笑. 1911. “Benbao chengwen li” 本報 徵文例 (This journal’s rules for soliciting manuscripts). Funü shibao 婦女時報 1 (June 11); 2 (July 26)， back matter.

37 On this notion of the intersection of big history with the smaller projects of everyday life, see Hershatter $(2011,24 ; 2012)$. 
1911, 1912, 1913. “Bianji shi” 編輯室 (From the office of the editor). Funü shibao 婦女時報 1 (June 11, 1911), 85; 2 (July 26, 1911), 56; 3 (September 22, 1911), 87; 5 (January 23, 1912), 75; 6 (May 1, 1912), 88; 9 (February 25,1913$), 92$.

1974. Chuanying lou huiyilu 釧影樓回憶錄 (Reminiscences of the bracelet shadow chamber). In Jindai Zhongguo shiliao congkan xubian diwuji 近代中 國史料叢刊續編 第五輯 (Collection of modern Chinese historical materials, continued, vol. 5), ed. Shen Yunlong 沈雲龍. Wenhai chubanshe.

Barlow, Tani E. 2004. The Question of Women in Chinese Feminism. Durham, NC: Duke University Press.

Chen Jianhua. 2008. "Canon Formation and Linguistic Turn: Literary Debates in Republican China, 1919-1949." In Beyond the May Fourth Paradigm: In Search of Chinese Modernity, ed. Kai-Wing Chow, Tze-ki Hon, Hung-yok Ip, and Don C. Price, 51-67. Lanham, MD: Lexington.

Cochran, Sherman. 2006. Chinese Medicine Men: Consumer Culture in China and Southeast Asia. Cambridge, MA: Harvard University Press.

Crow, Carl. 1937. Four Hundred Million Customers: The Experiences-Some Happy, Some Sad, of an American in China and What They Taught Him. New York: Harper.

Da, Nan, and Wang Zheng. 2015. "Feminist Sinologies: An Introduction.” Signs: Journal of Women in Culture and Society 40(3):545-62.

Elvin, Mark. 1989. "Tales of Shen and Xin: Body-Person and Heart-Mind in China during the Last 150 Years." In Fragments for a History of the Human Body: Part 2, ed. Michel Feher with Ramona Naddaff and Nadia Tazi, 266-359. New York: Zone.

Fan Boqun 范伯群 and Fan Zijiang 范紫江, eds. 1996. Yuanyang budie-Libai liu pai jingdian xiaoshuo wenku 鸳莺蝴蝶一礼拜六流派经典小说文库 [Archive of classic fiction by members of the Mandarin Duck and Butterfly and Saturday schools]. Nanjing: Jiangsu wenyi chubanshe.

Furth, Charlotte. 1999. A Flourishing Yin: Gender in China's Medical History, 960-1665. Berkeley: University of California Press.

Hershatter, Gail. 2011. The Gender of Memory: Rural Women and China's Collective Past. Berkeley: University of California Press.

- 2012. "Disquiet in the House of Gender." Journal of Asian Studies $71(4): 873-94$

Hockx, Michel. 2003. Questions of Style: Literary Societies and Literary Journals in Modern China, 1911-1937. Leiden: Brill.

Huang Kewu 黃克武. 1988. “Cong Shenbao yiyao guanggao kan minchu Shanghai de yiliao wenhua yu shehui shenghuo” 從申報醫藥廣告看民初上海的醫療 文化與社會生活 [A perspective on medical culture and social life in early Republican Shanghai from medical advertisements in Shenbao]. Zhongyang yanjiu yuan, Jindaishi yanjiu jikan, no. 17: 141-94.

. 2012. "Guanggao yu kuaguo wenhua fanyi: Ershi shiji chuqi Shenbao yiyao guanggao de zai sikao” 廣告與跨國文化翻譯：20世紀初期《申報》醫藥 廣告的再思考 [Medical advertising and cultural translation: The case of the 
Shenbao in early twentieth-century China]. Fanyishiyanjiu 《翻譯史研究》, no. 2: $130-54$.

Judge, Joan. 2008a. "Mediated Imaginings: Biographies of Western Women and Their Japanese Sources in Late Qing China.” In Different Worlds of Discourse: Transformations of Gender and Genre in Late Qing and Early Republican China, ed. Nanxiu Qian, Grace S. Fong, and Richard J. Smith, 147-66. Leiden: Brill.

- 2008b. The Precious Raft of History: The Past, the West, and the Woman Question in China. Stanford, CA: Stanford University Press.

- 2012. "Portraits of Republican Ladies: Materiality and Representation in Early Twentieth Century Chinese Photographs." In Visualising China. Moving and Still Images in Historical Narratives, ed. Christian Henriot and Yeh Wen-hsin, 131-70. Leiden: Brill.

- 2015. Republican Lens: Gender, Visuality, and Experience in the Early Chinese Periodical Press. Berkeley: University of California Press.

Ko, Dorothy. 1992. "Pursuing Talent and Virtue: Education and Women's Culture in 17th and 18th Century China." Late Imperial China 13(1):9-39.

Latham, Sean, and Mark S. Morrison. 2010. "Introduction." Journal of Modern Periodical Studies 1(1):iii-V.

Lee, Leo Ou-fan. 2001. "Incomplete Modernity: Rethinking the May Fourth Intellectual Project." In The Appropriation of Cultural Capital: China's May Fourth Project, ed. Milena Doleželová-Velingerová and Odřich Král, 31-65. Cambridge, MA: Harvard University Asia Center.

Link, E. Perry. 1981. Mandarin Ducks and Butterflies: Popular Fiction in Early Twentieth Century Chinese Cities. Berkeley: University of California Press.

Lyon, Janet. 2010. "Review of The Feminist Avant-Garde: Transatlantic Encounters of the Early Twentieth Century by Lucy Delap." Journal of Modern Periodical Studies 1(2):241-46.

Ma Guangren 马光仁 1996. Shanghai xinwen shi (1850-1949) 上海新闻史 (18501949) (History of the press in Shanghai [1850-1949]).Shanghai: Fudan daxue chuban she.

Mann, Susan. 2011. Gender and Sexuality in Modern Chinese History. Cambridge: Cambridge University Press.

Mitchell, W. J. T. 1994. Picture Theory: Essays on Verbal and Visual Representation. Chicago: University of Chicago Press.

Mittler, Barbara. 2013. "Imagined Communities Divided: Reading Visual Regimes in Shanghai's Newspaper Advertising (1860s-1920s)." In Visualising China: Moving and Still Images in Historical Narratives, ed. Christian Henriot and Yeh Wen-hsin, 267-377. Leiden: Brill.

“Nengzeng nüjie jueda zhi xingfu” 能增女界絕大之幸福 ([This product can] greatly enhance the happiness of women). 1911. Funü shibao 婦女時報 2 (July 26); 3 (September 22); 4 (November 5).

Qian, Nanxiu. 2008. "The Mother Nü xuebao versus the Daughter Nü xuebao: Generational Differences between 1898 and 1902 Women Reformers." In Different Worlds of Discourse: Transformations of Gender and Genre in Late Qing 
and Early Republican China, ed. Nanxiu Qian, Grace Fong, and Richard Joseph Smith, 257-91. Leiden: Brill.

Qiu Wu Suying 邱吳威英. 1916. “Meishu de fangzu fa” 美術的放足法 (An attractive method of unbinding the feet), Funü tanhua hui 婦女談話會 (Women’s conversation association). Funü shibao 18 (June), 74-5.

Qu Jun 翟鈞. 1911. "Funü zhi weisheng yi ban - yuejing zhi zhuyi/renshen zhi baoyang” 婦女之衛生一班- 月經之注意/ 妊娠之保飬 (A lesson on women's hygiene-menstruation care/pregnancy care). Funü shibao 婦女時報 3 (September 22), 25 .

Riley, Denise. 1988. "Am I That Name?" Feminism and the Category of "Women" in History. Minneapolis: University of Minnesota Press.

Sanger, J. W. 1921. "Advertising Methods in Japan, China, and the Philippines." Report, US Department of Commerce, Special Agent Series no. 209, Government Printing Office, Washington DC.

Scott, Joan Wallach. 2011. The Fantasy of Feminist History. Durham, NC: Duke University Press.

Sivin, Nathan. 1987. Traditional Medicine in Contemporary China: A Partial Translation of Revised Outline of Chinese Medicine (1972): With an Introductory Study on Change in Present Day and Early Medicine. Ann Arbor: Center for Chinese Studies, University of Michigan.

Tang Jianwo 湯劍我. 1911a. "Furen bing ji tazhong jibing zhi yundong liaofa" 婦人病及他種疾病之運動療法 (Exercises to cure gynecological problems and other illnesses). Funü shibao 婦女時報 4 (November 5), 75-76.

- 1911b. “[Jiating yundong] Shengticao” [家庭運動]繩體操 (Rope exercises [for the family]). Funü shibao 婦女時報 2 (July 26), 71-76.

—.1911c. “Nüzi xin youxi: mai hua sheng” 女子新游戲: 賣花聲 (New game for women: The song of selling flowers). Funü shibao 婦女時報 1 (June 11), $55-58$.

1911d. “Shuo nüzi zhi ticao” 說女子之體操 (Excercises for women). Funï shibao 婦女時報 3 (September 22), 7-10.

"Wo rufa fu le Luowei yaofang de guben zigong wan bing yong waizhi de shoushu wo zhongzhong shuo bu chu de bingzheng dou quanyu le zhenzhen shi fuke de lingdan miaofa ya” 我如法服了羅威藥房的固本子宮丸並用外治的手術我種種 說不出的病症都痊癒了真真是婦科的靈丹妙法呀 (After I took the Luowei Pharmacy's Guben Medicine for the Uterus as directed and underwent [external treatment], all my unnamable diseases were cured. This is really a miraculous cure for women). 1911. Funü shibao 婦女時報 2 (July 26).

Wu, Yi-li. 2010. Reproducing Women: Medicine, Metaphor, and Childbirth in Late Imperial China. Berkeley: University of California Press.

Xia Xiaohong 夏晓虹 comp. 2003. 《Nüzi shijie》wenxuan 《女子世界》文 (Selections from Women's world). Guiyang: Guizhou jiaoyu chubanshe.

“Xiangnan Lin Yingfei nushi fu Yueguang tiewan youxiao jiantai qilu liangzhang” 湘南林影斐女士服月光鐵丸有效見胎七律兩章 (The Yueguangtie pills have good 
effects on Ms. Lin Yingfei from Xiangnan. She composed two poems [to thank the drug maker]). 1911. Funü shibao 婦女時報 2 (July 26), back matter.

Xingyi 星一. 1911. “Meiguo funü zatan”美國婦女雜談 (Varied reflections on American women). Funü shibao 婦女時報 2 (July 26), 51-54.

Ye Yaling 葉雅玲. 2003. “Wenxue shiliao de yanjiu yunyong-yi 'Cong Qingmo zhi Wusi qianqi (1898-1919) nüxing baokan tantoa nüxing xin jiaose de kaizhan' weilie” 文學史料德研究運用—— 從清末至五四前期(1898-1919) 女性報刊探討女性新角色的開展 為例 (The research use of literary sourcesusing women's journals from the late Qing to the May Fourth period [18981919] to investigate the unfolding of new roles for women-as an example). Hanxue luntan 漢學論壇 3 (Taibei), 53-92.

Yin Yongqing 印永清. 2000. “Qingmo Minchu Shanghai funü baokan” 清末民初 上海妇女报刊 (Shanghai women's journals in the late Qing and early Repubic). Tushuguan zazhi 图书馆杂志 19:5, 50-53.

Yu Chien ming 游鑑明. 2009. Jindai huadong diqu de nüzi tiyu (1895-1937) 近代 華東地區的女子體育, 1895-1937 (On and off the playing fields: A modern history of physical education for girls in Eastern China [1895-1937]). Taipei: Institute of Modern History, Academia Sinica.

Zhang Zhaosi 張昭泗. 1916. “Zuzhi funü julebu zhi yijian” 組織婦女俱樂部之意見 (Opinion on organizing a women's club), Funü tanhua hui 婦女談話會 (Women's conversation association). Funü shibao 婦女時報 19 (August), 79-82. 